\title{
WhO MAKeS THE RULES OF GLOBALIZATION?
}

\author{
ALAN V. DEARDORFF \\ CESIFO WORKING PAPER No. 1301 \\ CATEGORY 7: TRADE POLICY \\ OCTOBER 2004 \\ Presented at CESifo Venice Summer Institute, \\ WORKSHOP ON DISSECTING GLOBALIZATION, JULY 2004
}

An electronic version of the paper may be downloaded

- from the SSRN website:

www.SSRN.com

- from the CESifo website:

www. CESifo.de 


\title{
WhO MAKES THE RULES OF GLOBALIZATION?
}

\begin{abstract}
In this paper I argue that profit-maximizing firms, even though they contribute to social welfare when they compete in the market, may not do so when they influence the political process. In particular, I suggest, through several examples from both the real world and from economic theory, that corporations have played a significant role in the formulation of the rules of the international trading system. They did this in the formation of the WTO, where they were responsible for the expansion to cover both intellectual property and services. And they do this in preferential trading arrangements such as the NAFTA, where they inserted the notorious Chapter 11 and specified rules of origin for automotive products. All of this is quite consistent with economic theory, including the literature on the political economy of trade policy. I also use a simple duopoly model to illustrate a domestic firm's interest in setting rules of origin. The corporate influence on rules need not be bad, but there is no reason why it should be good either, as these examples illustrate.
\end{abstract}

JEL Code: F13.

Keywords: political economy of trade, trade institutions.

\author{
Alan V. Deardorff \\ Department of Economics \\ University of Michigan \\ Ann Arbor, MI 48109-1220 \\ USA \\ alandear@umich.edu
}


Revised, August 26, 2004

\title{
Who Makes the Rules of Globalization?*
}

\author{
Alan V. Deardorff \\ The University of Michigan
}

\section{Introduction}

When economists think of globalization, most of us think first of free trade and therefore the gains from trade that we have been studying and teaching for two centuries. But actual globalization takes many forms, including not only trade but also foreign direct investment, financial capital flows, and sometimes even migration of labor. More importantly, even the liberalization of trade has not been the simple move to zero trade barriers that we understand from our models, but has taken the form of trade liberalization that was only partial. Some of this is multilateral, but with barriers only partially eliminated. And increasingly it is minilateral, with barriers removed more completely but only between pairs or among small groups of countries in free trade areas (FTAs) and the like.

Furthermore, in both of these cases the liberalization of trade typically is attached to a variety of other measures that may or may not generate the same sorts of benefits as reducing tariffs. Multilaterally, the WTO has expanded beyond the GATT to include services and intellectual property, as well as to address policies relevant to trade other than trade barriers. Minilaterally, FTAs routinely address issues other than trade, including not only investment but also labor standards and environment, the effects of

\footnotetext{
${ }^{*}$ I have benefited especially from the comments of participants at the CESifo conference in Venice.
} 
which may be very different from tariffs. And even for trade, because FTAs are only partial liberalization, they have features that may reduce or even reverse the beneficial effects of free trade. The importance of all of this is that, while we have a solid understanding from economic theory and experience of the benefits of multilateral free trade, these actual modes of globalization are something else.

Many of those who oppose or are skeptical of globalization - who tend not to be economists - base their doubts fundamentally on suspicion of corporations. Free trade increases the ability for large corporations to operate across national borders, thus - the skeptics would say - increasing their power over the economy and over peoples and governments around the world. Because corporations pursue only their self interest and not the social good, they exploit the world for their own profit. Thus Globalization $\equiv$ Corporate Power $\equiv$ Everybody Else Loses!

As economists we take issue with the second of these identities, and perhaps also with the first. Economic theory tells us, since Adam Smith, that firms, pursuing their self interest but competing with one another, lead, under ideal conditions at least, to maximizing well being for society as a whole. And indeed their competition among themselves reduces and, again under ideal conditions, even eliminates their own profits. So the fact that corporations are controlling economic activity does not, as long as they compete with each other or with smaller firms, mean that society loses. On the contrary, it is society that gains, and the corporations themselves find their profits competed away. Indeed, by this argument globalization itself may reduce corporate power by forcing large firms to compete with each other across borders, rather than allowing each to enjoy market power behind trade barriers. 
This would be fine if in fact globalization did entail simply the move to free trade. But as I have said, actual globalization includes both more and less than free trade. One implication of this is that the welfare theorems of trade theory need not apply, since their conditions are not met. This is the meaning of the Theorem of the Second Best, where partial moves toward free trade may be welfare reducing if other markets remain distorted. I am not too worried about that, however, except perhaps in cases where the importance of particular distortions and their implications for gains from trade are well established. I certainly would not in general want to reject partial trade liberalization based on just the vague fear that it may not be welfare improving. Distortions, after all, not only undermine the benefits of some moves toward liberalization; they also increase the benefits of others. ${ }^{1}$

My greater concern is that the particular ways that the world has embraced globalization have been selected for it not by obviously unbiased and high-minded academics, but rather by governments acting under the influence of special interests often corporate interests. That is, governments have negotiated both multilateral trade treaties and minilateral preferential arrangements in response to, and in the presence of, pressures brought to bear upon them by domestic interests. These interests could take a variety of forms, and in principle could represent very broad constituencies. But in practice it seems clear that corporate interests have so far dominated. And while economic theory is reassuring about the effects of the profit motive when it drives behavior in the marketplace, there is no such reason to trust its effects in the political

\footnotetext{
${ }^{1}$ For example, suppose we know that a domestic industry provides a positive externality that somehow cannot be internalized through a first-best production subsidy. Then while this means that a tariff may be beneficial if the industry competes with imports, it also means that a tariff (on another good) is even more harmful than usual if the industry exports.
} 
arena. In short, my concern in this paper is that the influence of producers, especially of large corporations, has dominated the drafting of the texts of international economic agreements and has done so, understandably, so as to promote the interests of those producers. Their interests are not necessarily harmful to society, but they are not necessarily beneficial either. And there is no reason to expect an invisible hand to guide governments that are under corporate influence toward desirable outcomes.

In the remainder of this paper I will first, in section II, elaborate on some particular examples of corporate influence that are suggested by casual observation. Most of these are ones that I mentioned when I first began to worry about this issue in Deardorff (2003). I will then turn, in section III, to looking at what economic theory can suggest about this process in the context specifically of FTAs. I will first review the implications of some existing literature for this issue, then provide my own simple example of how producer interests might seek to determine rules of origin.

\section{Episodes of Corporate Influence}

\section{TRIPs}

I will start with what to me is the most egregious example of corporate influence on international rulemaking: the Uruguay Round Agreement on Trade Related Intellectual Property Rights (TRIPs). When issues of intellectual property rights (IPRs) first began to be discussed as part of the Uruguay Round, the claim was that any new rules would be confined to their "trade related" aspects. That presumably referred to the entry of IPRviolating goods into international trade, especially the export of such goods into a country where the IPR was established and enforced. It is not clear that new rules were needed 
for that, but in any case the negotiations soon left that narrow problem behind. The resulting TRIPs agreement requires that all WTO member countries enact and enforce IPR laws that are roughly comparable to those in the developed countries. The effect of this, since most IPRs are owned by developed-country firms, has been to force developing countries to protect the IPRs of individuals and firms in the developed countries. And this, aside from any stimulus it might provide to the creation of intellectual property of particular use to developing countries, is a change that can only benefit rich-country owners of IPRs and harm poor-country consumers. A case can of course be made for IPR protection as a second-best means of simulating innovation. But I have argued in Deardorff $(1990,1992)$ that, even on efficiency grounds, extending IPR protection to the whole world is going too far. And developing countries - notably India - resisted this effort to bring IPRs into the rules of the world trading system.

So why did this effort succeed? Clearly because of corporate influence. A group of very large corporations especially in the pharmaceutical industry were, as I understand it, the initiators of the push for TRIPs in these negotiations, and they played an active role in moving the negotiations along. It was they, after all, who depended most heavily on the defense of IPRs, since their products, once developed, can be imitated at very low cost. It was in their interest of course to prevent the importation into the U.S. and Europe of unlicensed generic drugs manufactured in, say, India. But once they entered the international rule-making arena, they did not stop there. They pushed to have the international trading system override the decision that many developing countries had made, that the short-term health of their populations was more important than the profits of the big drug companies. I say "short-term" here because in making this choice they 
were almost certainly giving up the chance for new drugs to be developed of particular interest to those same populations. Whether they understood that cost or not, I don't know, but it was the choice they had made. And the drug companies sought to rule that choice essentially illegal.

My point is not that the TRIPs agreement is harmful, even though I may believe that it is. My point is that the TRIPs agreement was negotiated for reasons that had nothing to do with whether it was harmful or not, but only to do with whether it would increase the profits of some powerful corporations. And I am not saying either that these corporations were behaving badly. I happen to think that pharmaceutical companies have made a huge contribution to the well-being of modern society, and I do not generally begrudge them the large profits that they earn when one of their discoveries is a success. Their pursuit of profit through research and development as well as marketing has, I am quite willing to believe, made the world a better place.

The problem is that they were permitted to pursue profit not just in their industry but also by influencing international negotiations on the rules that they themselves would play by. And not surprisingly, they used their power to design those rules to their own maximum advantage. They could hardly have been expected not to. The error was in letting them influence the negotiations in the first place. In their particular case, it would not have been hard to prevent this, since the relevance of their concerns for trade negotiations was always suspect. They could have been told to take their case to the World Intellectual Property Organization, rather than to GATT and the WTO. 


\section{GATS}

I claim that there is no reason to expect corporate influence on rule making to be beneficial. But there is also no reason to expect it to be harmful. My second example, I believe, demonstrates this. Prior to the Uruguay Round, the GATT covered only trade in goods. Indeed, international transactions in services were not even regarded as trade. Since they typically required some sort of producer presence in the country consuming the service, they were considered to be part of foreign direct investment, and so were subject to much weaker disciplines on restrictive policies than the rules governing trade policy under the GATT.

At some point during the 1980s, I am told, participants in certain service industries got the idea of arguing that what they did was trade after all, and that it should be covered under GATT. They made this case to the U.S. government, which in turn placed services on the agenda of the Uruguay Round. The end result was not, of course, to include services in the GATT per se, which continues to be the central pillar of the WTO, but instead to negotiate a new General Agreement on Trade in Services (GATS) to provide its own discipline to service transactions.

This made good sense, in two respects. First, many have argued that the gains from international service transactions are just as real as the gains from trade in goods, and indeed the economic causes and effects are very much the same. I made this case myself early on, in Deardorff (1985).

On the other hand, the policies that are applied to services are quite different from the policies that are applied to trade in goods, and they do not even include anything that is exactly comparable to the tariffs that were the original focus of the GATT. So the 
same rules could not apply directly, and it made sense to negotiate a new agreement to cover services.

The GATS itself did not accomplish much liberalization, if any, although some has come in subsequent agreements. And there are disagreements about how liberalization in these markets ought to proceed. But my point here is simply to note that these issues might never have been addressed had it not been for the influence of American corporate executives in the service industries who saw an opportunity and pressed their case. They did it, I presume, primarily to benefit themselves and their firms, but in this case economics is very much on their side and I think the world as a whole stands to benefit.

Not all would agree with this, of course. Precisely because services are interlinked with FDI, the import of services can be seen as even more threatening to a country's domestic interests than imports of goods. And furthermore, the perception that many service industries were dominated by large corporations from rich countries created the fear that, in these industries, developing countries stood only to lose from freer trade.

Of course this second concern is exactly what trade following comparative advantage is all about, and while competing industries may lose, their countries gain from services that are more efficiently supplied. Indeed, one can argue that the gains from trade are even larger here than in many goods industries, because so many services provide essential inputs, including infrastructure, for other industries. Access to worldclass service providers might well allow some developing-country manufacturing industries to exploit a comparative advantage that would otherwise be undermined by the need to use expensive and low quality local services. 


\section{NAFTA Chapter 11}

The NAFTA agreement was a massive document, and those of us who tried to analyze the likely effects of NAFTA tended to focus on those few aspects of it that we best understood. Not surprisingly, there were pieces of it that we neglected, some that we failed even to know about. One of these that later drew a good deal of public attention was Chapter 11, on investment. Motivated by concern that a government might expropriate the property of a foreign direct investor, Chapter 11 requires that any such expropriation, direct or indirect, be accompanied by appropriate compensation. Furthermore, it entitles the victim of such expropriation to bring a case before a NAFTA tribunal against the national government of the country where the expropriation took place.

This, it turns out, may provide a powerful tool for corporations in one NAFTA country to use against governments (including state and local) in another NAFTA country, whenever a government uses a policy or regulation that reduces the corporation's profit. Or so it seems, at least from the cases that have been brought. All three NAFTA governments have been named in such cases. Opponents of NAFTA point especially to attempts at environmental regulation that have been challenged under Chapter 11 on the grounds that they reduce the profit of a foreign NAFTA firm. The most visible such case has been against the US by the Canadian Methanex Corporation, seeking compensation for a California prohibition against a fuel additive they supplied that had been judged to be toxic.

This particular case is still pending, so it is too soon to know how it will be decided. Of the 22 other cases that have been brought under Chapter 11, only five have 
led to decisions - three of them positive - while others have been settled or withdrawn. I find it hard to judge the merits of these cases, since many who write about this issue do not even pretend to be unbiased. But my impression is that the panels deciding these cases have been far less expansive than the NAFTA opponents feared.

However, my point here is not to argue the merits of Chapter 11 and the way it has been administered. Rather what I want to stress is the unprecedented nature of the agreement itself, in two respects. First, as I said above, Chapter 11 covers not just direct expropriation - as when a government takes over ownership of foreign firm's property but also indirect. What that actually means remains to be determined by the cases as they are brought and decided, but as the Methanex case suggests, some would argue that indirect expropriation includes policy changes that reduce the value of a foreign investment. As I understand it (which admittedly is not very well), that could turn out to be an expansion of property rights beyond what most countries, including the United States, include in domestic law.

Second, and perhaps more importantly, Chapter 11 allows an unprecedented right of private action against the government of another country to be decided by an international tribunal. Prior to NAFTA - in the US-Canada FTA for example, and also in the GATT - such tribunals were available in trade law only for disputes between governments. But NAFTA does not require that an aggrieved private party go through its own government; it files the case directly against the government of another country.

So why did NAFTA come to include such an unusually strong facility for private action? I myself know little about how NAFTA was negotiated and nothing at all about the origin of Chapter 11. But consider who gains from Chapter 11. On the one hand, 
companies from NAFTA countries that invest in other NAFTA countries gain, either leverage over policies that might harm them or substantial compensation, if their cases succeed or induce a settlement in their favor. On the other hand, the countries themselves may gain from a higher level of direct investment, as foreign investors are reassured by Chapter 11 against the risk of adverse policy decisions. But if the latter was the dominant factor in motivating Chapter 11, one has to wonder why governments eager to attract FDI could not have provided such reassurance more directly with their own laws. The likelihood therefore seems high that Chapter 11 was written expressly for the companies that stood to benefit from it. And the impression that this was the case seems heightened by the fact that nobody spoke of Chapter 11 when the NAFTA agreement was being debated.

So regardless of the merits of Chapter 11, its existence strikes me as fairly strong evidence, once again, of the power of corporate interests in setting the rules of the international trading system.

\section{NAFTA Rules of Origin}

Because it is a free trade area rather than a customs union, thus leaving external tariffs unchanged and usually different for imports of the same good into different member countries, the NAFTA must include rules of origin. That is, for a good to cross from one NAFTA country to another free of tariff, it must be regarded as having "originated" within NAFTA, and the word "originated" must be defined. What this definition should be is not obvious, and it can matter a great deal as I will illustrate in section III below. 
Economists have examined the effects of various rules of origin, without any consensus emerging as to what they should be. ${ }^{2}$

Two plausible candidates would base origin on either the percentage of domestic value added or on changes in tariff classification between inputs and outputs. The NAFTA Chapter 4, on rules of origin, uses both of these criteria and more, in an elaborate series of provisions that I suspect only a team of lawyers and accountants together could understand. The complexity of these rules must itself discourage some producers from attempting to take advantage of the tariff preferences that NAFTA provides. I have no idea whether the complexity is a deliberate attempt to discourage trade, or is only the natural outcome of compensating the drafters of the agreement in proportion to the time they spend on it.

But there is one aspect of the NAFTA rules of origin whose purpose seems more explicit. The fourth article of Chapter 4 deals exclusively with Automotive Goods, spelling out rules of origin for these that are even more explicit, detailed, and (to me) opaque than for other goods. Are these more restrictive than the rest of NAFTA's rules of origin? I certainly cannot tell from reading the text. But I do happen to know that this text was drafted by a group that included at least one economist who was an employee of a U.S. auto company. And that person's purpose was to draft rules that would permit his or her company to export tariff free from Mexico to the U.S. while preventing its Japanese competitors from doing the same. In Section III I will give an example of how this might be possible, in case it is not obvious.

So it appears that, by having American firms at the table in drafting rules of origin, at least in the automotive sector, the NAFTA was explicitly designed to benefit

\footnotetext{
${ }^{2}$ See Krishna (2004) for a recent survey of this literature.
} 
certain US corporations. Was this the intent of the U.S. government? Perhaps, but not necessarily. For all I know there may be a good reason why the automotive sector cannot be handled by the same rules as others, and if so then the expertise to write the rules would certainly not lie in USTR, whose staff should be experts on trade, not automobiles. To whom should they turn to assist them if not experts from the auto industry, with US auto companies being the natural choice? But once in the room, those experts can hardly be expected to represent the interests of Japanese or European firms.

\section{Other?}

These four examples of the role that corporate influence has apparently played, two in the WTO and two in NAFTA, are just the examples that I happen to know about and think I understand. Given the extreme complexity of both of these agreements and the fact that corporate representatives certainly were involved during their negotiations, if not as parties to the negotiations then as advisors to the negotiators, I have to believe that there are many other perhaps smaller ways that corporate interests have been represented. It is of course not in their interest to draw attention to these.

\section{What Theory Says}

\section{Political Economy of Trade Policy}

Trade economists have been led to look at political forces mainly by the otherwise inexplicable reluctance of governments to take our advice. After all, we have been very consistent for two centuries in advising all who will listen that governments should not interfere with trade. There are exceptions to our case for free trade, but we have always found credible counter-arguments to them. In the end, even those of us who have been 
most creative in constructing cases where protection might be beneficial have ultimately agreed that the economic interests of countries are best served by eliminating tariffs and other barriers to trade. ${ }^{3}$ Yet hardly any country in history seems to have listened. Given the choice between believing that we were wrong, or that they were pursuing something other than their economic interests, we naturally chose the latter.

Hence the theories of political economy of trade have focused on explaining why import tariffs were positive. This literature, which has been surveyed frequently, ${ }^{4}$ seems to have converged on the model of Grossman and Helpman (1994) as the standard. In this model, a specific factor in each industry benefits from a tariff on its output, and the owners of specific factors are motivated by this to contribute toward the election of incumbent politicians in return for protection. Politicians in turn maximize a combination of social welfare and these contributions, with the result that they provide positive protection.

The Grossman-Helpman model says rather directly that owners of capital (as a specific factor) exert influence on international trade policy through political contributions. The model has also received some empirical support from Goldberg and Maggi (1999), although with a higher weight on social welfare than many might have expected. It does not, however, address the making of the rules of trade policy, but only the setting of tariffs within rules that have already been made.

However, a subsequent application of the Grossman-Helpman model comes closer to addressing rule making. In Grossman and Helpman (1995), they use the same model to examine the formation of FTAs. And after applying their framework in the first

\footnotetext{
${ }^{3}$ See Krugman (1987).

${ }^{4}$ See Rodrik (1995), Helpman (1999).
} 
part of the paper just to the binary problem of whether to agree on an FTA with a given partner or not, they then turn to the question of exclusions. That is, actual FTAs do not always eliminate tariffs on absolutely every sector of the economy, and instead may exempt certain "sensitive" sectors. What are those sectors likely to be sensitive to? Politics, of course, and Grossman and Helpman show how the selection of exempted sectors will depend, as do tariffs in their first application, on contributions from specific factors in exempted industries. And these in turn depend on the extra returns that these specific factors stand to gain (or avoid losing) by being exempted. This, then, is an example of corporate influence over the rules of an FTA, if we equate corporate profits with returns to specific factors.

Another example is provided by Krishna (1998). He uses a model of imperfect competition and political economy to examine how the political process might favor one choice of FTA partner over another, and how both might compare to an alternative of multilateral liberalization. What he finds is that, the more likely is an FTA to be trade diverting and therefore welfare reducing, the more likely it is to be selected by the political process, over other potential FTAs and over multilateral liberalization. Thus, again, the rules of trade policy in the form of FTAs are influenced by the profits of those sectors that stand to gain. It should be said, however, that political-economy models of issues like this do not necessarily rest on the influence of owners of capital. Levy (1997), for example, examines how FTAs influence the choice of multilateral liberalization, but in a median voter model. 


\section{Rules of Origin - A Theoretical Example}

I turn now to a theoretical example that is focused more explicitly on the determination of one of the rules of international trade - specifically, a rule of origin in an FTA. I will show a simple model in which a domestic firm stands to increase its profit by setting a rule of origin that favors it over its foreign competitor, thus giving it the incentive to influence the formulation of that rule in whatever way it can. As will be clear, the model attempts to formalize what seems to have been going on in the NAFTA rules of origin in automotive goods, as discussed above. I do not model the political process, which I presume could be similar to that of Grossman and Helpman, although I will conclude with a brief discussion of an alternative mechanism that might more plausibly have the same effect.

Consider a simple model of Bertrand duopoly. That is, there are two firms that are the only suppliers of a single differentiated product to the market in country U, one of them based in country $U$ and the other in another country, J. Production requires an intermediate input that each can produce only in its own country, due to a specialized factor, perhaps expertise, that is available only there and that is needed to sustain the final product's differentiated characteristics. Their costs for this input are constants, $b^{U}$ and $b^{J}$ respectively, for the quantity needed to produce one unit of the final good. The input can then be assembled at constant cost, the same for both of them, in either country $U$ or country $\mathrm{J}$, and also in another country, $\mathrm{M}$, which will become the partner in an FTA with country $\mathrm{U}$. These costs of assembly are $c^{U}, c^{J}$, and $c^{M}$, of which I will assume $c^{U}=c^{J}>c^{M}$. The firms face demand functions in country $\mathrm{U}, D^{U}=D^{U}\left(p^{U}, p^{J}\right)$ and $D^{J}=D^{J}\left(p^{J}, p^{U}\right)$ respectively, where $p^{i}$ is the price of firm $i$ 's product in country $\mathrm{U}$. 
The demand functions are linear, as I will specify below. Initially, country U levies a specific tariff, $t>\left(c^{U}-c^{M}\right)$, on imports of the final good from either other country, so that both firms do assembly in country U. Later I will have country U form an FTA with country $\mathrm{M}$, eliminating this tariff on imports from there but subject to a rule of origin.

Formally, then, the model has two firms, A and B, each with constant unit costs of production $k^{i}, i=A, B$. They face demands for their products given by

$$
D^{i}=a^{i}-p^{i}+s p^{j}, \quad i \neq j=A, B
$$

where $a^{i}>0,0<s<1$ are parameters. ${ }^{5}$ That is, demand for each is downward sloping in its own price, but increases in the price of its competitor. Each firm's profit is therefore

$$
\pi^{i}=\left(p^{i}-k^{i}\right)\left(a^{i}-p^{i}+s p^{j}\right)
$$

With Bertrand competition, each firm selects its price to maximize this profit given the price of the other. First order conditions for this maximization imply their reaction functions,

$$
p^{i}=\left(a^{i}+k^{i}+s p^{j}\right) / 2
$$

which together yield equilibrium prices

$$
p^{i}=\Omega\left(A^{i}+2 k^{i}+s k^{j}\right)
$$

where

$$
\Omega=1 /\left(4-s^{2}\right), \quad A^{i}=2 a^{i}+s a^{j}
$$

Profits in equilibrium turn out to be

$$
\pi^{i}=\Omega^{2}\left(A^{i}-\left(2-s^{2}\right) k^{i}+s k^{j}\right)^{2}
$$

\footnotetext{
${ }^{5}$ The upper bound on $s, s<1$, is only to assure the plausible property that equal increases in both prices reduce demand, but only $s<2$ turns out to be needed for the model to be well behaved.
} 
Applying this result to the firms $\mathrm{U}$ and $\mathrm{J}$, before the FTA we have their input costs as $b^{U}$ and $b^{J}$ respectively, but a common assembly cost in country $\mathrm{U}, c^{U}$. Thus, in the notation of the model, $k^{U}=b^{U}+c^{U}$ and $k^{J}=b^{J}+c^{U}$. Using (6), their pre-FTA profits are

$$
\begin{aligned}
& \pi^{U}=\Omega^{2}\left(A^{U}-\left(2-s^{2}\right)\left(b^{U}+c^{U}\right)+s\left(b^{J}+c^{U}\right)\right)^{2} \\
& \pi^{J}=\Omega^{2}\left(A^{J}-\left(2-s^{2}\right)\left(b^{J}+c^{U}\right)+s\left(b^{U}+c^{U}\right)\right)^{2}
\end{aligned}
$$

After the FTA, firm U can do assembly in the cheaper country M, since its exports from $\mathrm{M}$ back to $\mathrm{U}$ will easily satisfy any rule of origin, having been produced entirely in $\mathrm{U}$ and M. Thus, letting “^” denote the FTA, $k^{U}$ becomes $\hat{k}^{U}=b^{U}+c^{M}<k^{U}$. Firm J, on the other hand, since its input comes from outside the FTA, if it were to assemble in country $\mathrm{M}$ would fail to satisfy any rule of origin that, say, requires content from within the FTA countries of more than $c^{M} /\left(b^{J}+c^{M}\right)$ percent. Assuming this is the case, then firm $\mathrm{J}$ continues to assemble in $\mathrm{U}$ and its cost continues to be $\hat{k}^{J}=k^{J}=b^{J}+c^{U}$. Applying these costs to (6), we find the FTA profits of the firms to be

$$
\begin{aligned}
& \hat{\pi}^{U}=\Omega^{2}\left(A^{U}-\left(2-s^{2}\right)\left(b^{U}+c^{M}\right)+s\left(b^{J}+c^{U}\right)\right)^{2} \\
& \hat{\pi}^{J}=\Omega^{2}\left(A^{J}-\left(2-s^{2}\right)\left(b^{J}+c^{U}\right)+s\left(b^{U}+c^{M}\right)\right)^{2}
\end{aligned}
$$

Comparing (8) with (7),

$$
\begin{aligned}
& \hat{\pi}^{U}=\left(\sqrt{\pi^{U}}+\Omega\left(2-s^{2}\right)\left(c^{U}-c^{M}\right)\right)^{2}>\pi^{U} \\
& \hat{\pi}^{J}=\left(\sqrt{\pi^{J}}-\Omega s\left(c^{U}-c^{M}\right)\right)^{2}<\pi^{J}
\end{aligned}
$$

Thus, a rule of origin, which can prevent firm $\mathrm{J}$ from taking advantage of the lower cost assembly in country $\mathrm{M}$ while firm $\mathrm{U}$ avails itself of it through the FTA, both raises the profit of firm $U$ and lowers the profit of firm J. This is hardly surprising, and in the example here it can be achieved very simply: just specify as a rule of origin that 
imports from $\mathrm{M}$ to $\mathrm{U}$ will be duty free only if they have content from among the FTA countries of more than $\Gamma=c^{M} /\left(b^{J}+c^{M}\right)$ percent. That would easily be satisfied by an FTA content requirement of $100 \%$, but since that might be too blatantly protectionist, the firm may be expected instead to use its knowledge of the industry to seek a lower content requirement, but high enough to achieve the same purpose, just more than $\Gamma$.

I have not attempted here to model the means by which a firm in this situation might influence the writing of the rule of origin. The Grossman-Helpman story, I suppose, would be that the firm would offer a financial contribution of some sort to incumbent politicians in return for their setting a content requirement in this industry of more than $\Gamma$. Whether this would succeed or not would depend on how the politician weights the financial contribution (which is limited by the gain in profit that is implicit in (9)) against the loss in economic welfare for the country as a whole. Realistically it would also depend on whether the politician can manage to influence the negotiations on the FTA at the level that would make this possible.

A more plausible story for political influence in this context is suggested by Hall (2001). ${ }^{6}$ In his description of lobbying, private interests do not in any sense pay money to politicians. Rather, they help them. That is, recognizing the limited time and resources that legislators have to accomplish their many objectives, only one of which is being re-elected, they welcome assistance from lobbyists who assist them by doing research and drafting legal texts on issues of their common interest. Hall points out first that a great deal of lobbying takes place, not between lobbyists and the politicians whom they wish to sway to agree with them, but between lobbyists and politician who are

\footnotetext{
${ }^{6}$ See also Deardorff and Hall (1997).
} 
already their friends - the politicians who because of ideology or their constituencies already wish to achieve the same objectives as the lobbyists. Such behavior makes no sense from the perspective of other models of political economy. For example, in Grossman and Helpman's story, a firm would never pay a politician to vote for a tariff that he or she already favored on grounds of social welfare. But it does make sense if by helping the politician the lobbyist can help to make progress toward their common objective. The result of this is that lobbyists and their staff members play an active role in formulating policy.

Hall's theory is intended to explain the interaction between lobbyists and legislators, but the idea seems to extend easily to the executive branch. The office of U.S. Trade Representative, in particular, is surprisingly small in proportion to the size of its mission, and, I would guess, needs all the help it can get. In addition, the negotiations that it undertakes necessarily involve the intricacies of many individual industries, and even a much larger USTR staff would be unlikely to possess the expertise needed to deal with these. Therefore it is natural for trade negotiators to enlist the assistance of willing participants from domestic industries who have this expertise. And that gives the industries access to the drafting of trade agreements. It is through this mechanism, it seems, that trade rules negotiated by the U.S. government come to represent the interests of domestic industries.

\section{IV.Conclusion}

In this paper I have argued that profit maximizing firms, even though they contribute to social welfare when they compete in the market, may not do so when they influence the 
political process. In particular, I have suggested, through several examples from both the real world and from economic theory, that corporations have played a significant role in the formulation of the rules of the modern international trading system. They do this both in the multilateral system overseen by the WTO, and within regional trade agreements such as NAFTA. Their influence on rules need not be bad, but there is no reason why it should be good either. We therefore need to give more thought to constraining not just trade policy, but also the making of the rules of trade, to try to assure that this process moves us to a better world. 


\section{References}

Deardorff, Alan V. 1985 "Comparative Advantage and International Trade and Investment in Services," in Robert M. Stern, (ed.), Trade and Investment in Services: Canada/US Perspectives, Toronto: Ontario Economic Council, pp. 39 71.

Deardorff, Alan V. 1990 "Should Patent Protection Be Extended to All Developing Countries," The World Economy 13, (December), pp. 497-507.

Deardorff, Alan V. 1992 "Welfare Effects of Global Patent Protection," Economica 59, (February), pp. 35-51.

Deardorff, Alan V. 2003 "What Might Globalization's Critics Believe?" The World Economy 26, (May), pp. 639-658.

Deardorff, Alan V. and Richard L. Hall 1997 "Explaining the Role of Interest Groups in United States Trade Policy," Research Seminar in International Economics Discussion Paper No. 415, University of Michigan.

Goldberg, Pinelopi Koujianou and Giovanni Maggi 1999 "Protection for Sale: An Empirical Investigation," American Economic Review 89, (December), pp. 11351155.

Grossman, Gene M. and Elhanan Helpman 1994 "Protection for Sale," American Economic Review 84, (September), pp. 833-850.

Grossman, Gene M. and Elhanan Helpman 1995 "The Politics of Free-Trade Agreements," American Economic Review 85(4), (September), pp. 667-690.

Hall, Richard L 2001 "Lobbying as Legislative Subsidy," paper presented at the annual meetings of the American Political Science Association.

Helpman, Elhanan 1999 "Politics and Trade Policy," in Richard Baldwin et al. eds., Market Integration, Regionalism, and the Global Economy, Cambridge: Cambridge University Press, pp. 86-112.

Krishna, Kala. 2004 "Understanding Rules of Origin," in process, February 11.

Krishna, Pravin 1998 "Regionalism and Multilateralism: A Political Economy Approach," Quarterly Journal of Economics 113, (February), pp. 227-251.

Krugman, Paul R. 1987 “Is Free Trade Passé?” Journal of Economic Perspectives 1, (Fall), pp. 131-144.

Levy, Philip I. 1997 “A Political-Economic Analysis of Free-Trade Agreements,” American Economic Review 87, (September), pp. 50-519.

Rodrik, Dani 1995 "Political Economy of Trade Policy," in G. Grossman and K. Rogoff, eds., Handbook of International Economics, Vol. III, Amsterdam: NorthHolland. 


\section{CESifo Working Paper Series}

(for full list see www.cesifo.de)

1241 Hans Jarle Kind, Karen Helene Midelfart, Guttorm Schjelderup, Corporate Tax Systems, Multinational Enterprises, and Economic Integration, July 2004

1242 Vankatesh Bala and Ngo Van Long, International Trade and Cultural Diversity: A Model of Preference Selection, July 2004

1243 Wolfgang Eggert and Alfons J. Weichenrieder, On the Economics of Bottle Deposits, July 2004

1244 Sören Blomquist and Vidar Christiansen, Taxation and Heterogeneous Preferences, July 2004

1245 Rafael Lalive and Alois Stutzer, Approval of Equal Rights and Gender Differences in Well-Being, July 2004

1246 Paolo M. Panteghini, Wide vs. Narrow Tax Bases under Optimal Investment Timing, July 2004

1247 Marika Karanassou, Hector Sala, and Dennis J. Snower, Unemployment in the European Union: Institutions, Prices, and Growth, July 2004

1248 Engin Dalgic and Ngo Van Long, Corrupt Local Government as Resource Farmers: The Helping Hand and the Grabbing Hand, July 2004

1249 Francesco Giavazzi and Guido Tabellini, Economic and Political Liberalizations, July 2004

1250 Yin-Wong Cheung and Jude Yuen, An Output Perspective on a Northeast Asia Currency Union, August 2004

1251 Ralf Elsas, Frank Heinemann, and Marcel Tyrell, Multiple but Asymmetric Bank Financing: The Case of Relationship Lending, August 2004

1252 Steinar Holden, Wage Formation under Low Inflation, August 2004

1253 Ngo Van Long and Gerhard Sorger, Insecure Property Rights and Growth: The Roles of Appropriation Costs, Wealth Effects, and Heterogeneity, August 2004

1254 Klaus Wälde and Pia Weiß, International Competition, Slim Firms and Wage Inequality, August 2004

1255 Jeremy S. S. Edwards and Alfons J. Weichenrieder, How Weak is the Weakest-Link Principle? On the Measurement of Firm Owners' Control Rights, August 2004

1256 Guido Tabellini, The Role of the State in Economic Development, August 2004 
1257 François Larmande and Jean-Pierre Ponssard, EVA and the Controllability-congruence Trade-off: An Empirical Investigation, August 2004

1258 Vesa Kanniainen and Jenni Pääkkönen, Anonymous Money, Moral Sentiments and Welfare, August 2004

1259 Panu Poutvaara and Andreas Wagener, Why is the Public Sector More Labor-Intensive? A Distortionary Tax Argument, August 2004

1260 Lars P. Feld and Stefan Voigt, Making Judges Independent - Some Proposals Regarding the Judiciary, August 2004

1261 Joop Hartog, Hans van Ophem, and Simona Maria Bajdechi, How Risky is Investment in Human Capital?, August 2004

1262 Thomas Eichner and Rüdiger Pethig, Efficient Nonanthropocentric Nature Protection, August 2004

1263 David-Jan Jansen and Jakob de Haan, Look Who's Talking: ECB Communication during the First Years of EMU, August 2004

1264 David F. Bradford, The X Tax in the World Economy, August 2004

1265 Hans-Werner Sinn, Migration, Social Standards and Replacement Incomes. How to Protect Low-income Workers in the Industrialized Countries against the Forces of Globalization and Market Integration, August 2004

1266 Wolfgang Leininger, Fending off one Means Fending off all: Evolutionary Stability in Submodular Games, August 2004

1267 Antoine Bommier and Bertrand Villeneuve, Risk Aversion and the Value of Risk to Life, September 2004

1268 Harrie A. A. Verbon and Lex Meijdam, Too Many Migrants, Too Few Services: A Model of Decision-making on Immigration and Integration with Cultural Distance, September 2004

1269 Thomas Eichner and Rüdiger Pethig, Economic Land Use, Ecosystem Services and Microfounded Species Dynamics, September 2004

1270 Federico Revelli, Performance Rating and Yardstick Competition in Social Service Provision, September 2004

1271 Gerhard O. Orosel and Klaus G. Zauner, Vertical Product Differentiation When Quality is Unobservable to Buyers, September 2004

1272 Christoph Böhringer, Stefan Boeters, and Michael Feil, Taxation and Unemployment: An Applied General Equilibrium Approach, September 2004 
1273 Assaf Razin and Efraim Sadka, Welfare Migration: Is the Net Fiscal Burden a Good Measure of its Economics Impact on the Welfare of the Native-Born Population?, September 2004

1274 Tomer Blumkin and Volker Grossmann, Ideological Polarization, Sticky Information, and Policy Reforms, September 2004

1275 Katherine Baicker and Nora Gordon, The Effect of Mandated State Education Spending on Total Local Resources, September 2004

1276 Gabriel J. Felbermayr and Wilhelm Kohler, Exploring the Intensive and Extensive Margins of World Trade, September 2004

1277 John Burbidge, Katherine Cuff and John Leach, Capital Tax Competition with Heterogeneous Firms and Agglomeration Effects, September 2004

1278 Joern-Steffen Pischke, Labor Market Institutions, Wages and Investment, September 2004

1279 Josef Falkinger and Volker Grossmann, Institutions and Development: The Interaction between Trade Regime and Political System, September 2004

1280 Paolo Surico, Inflation Targeting and Nonlinear Policy Rules: The Case of Asymmetric Preferences, September 2004

1281 Ayal Kimhi, Growth, Inequality and Labor Markets in LDCs: A Survey, September 2004

1282 Robert Dur and Amihai Glazer, Optimal Incentive Contracts for a Worker who Envies his Boss, September 2004

1283 Klaus Abberger, Nonparametric Regression and the Detection of Turning Points in the Ifo Business Climate, September 2004

1284 Werner Güth and Rupert Sausgruber, Tax Morale and Optimal Taxation, September 2004

1285 Luis H. R. Alvarez and Erkki Koskela, Does Risk Aversion Accelerate Optimal Forest Rotation under Uncertainty?, September 2004

1286 Giorgio Brunello and Maria De Paola, Market Failures and the Under-Provision of Training, September 2004

1287 Sanjeev Goyal, Marco van der Leij and José Luis Moraga-González, Economics: An Emerging Small World?, September 2004

1288 Sandro Maffei, Nikolai Raabe and Heinrich W. Ursprung, Political Repression and Child Labor: Theory and Empirical Evidence, September 2004 
1289 Georg Götz and Klaus Gugler, Market Concentration and Product Variety under Spatial Competition: Evidence from Retail Gasoline, September 2004

1290 Jonathan Temple and Ludger Wößmann, Dualism and Cross-Country Growth Regressions, September 2004

1291 Ravi Kanbur, Jukka Pirttilä and Matti Tuomala, Non-Welfarist Optimal Taxation and Behavioral Public Economics, October 2004

1292 Maarten C. W. Janssen, José Luis Moraga-González and Matthijs R. Wildenbeest, Consumer Search and Oligopolistic Pricing: An Empirical Investigation, October 2004

1293 Kira Börner and Christa Hainz, The Political Economy of Corruption and the Role of Financial Institutions, October 2004

1294 Christoph A. Schaltegger and Lars P. Feld, Do Large Cabinets Favor Large Governments? Evidence from Swiss Sub-Federal Jurisdictions, October 2004

1295 Marc-Andreas Mündler, The Existence of Informationally Efficient Markets When Individuals Are Rational, October 2004

1296 Hendrik Jürges, Wolfram F. Richter and Kerstin Schneider, Teacher Quality and Incentives: Theoretical and Empirical Effects of Standards on Teacher Quality, October 2004

1297 David S. Evans and Michael Salinger, An Empirical Analysis of Bundling and Tying: Over-the-Counter Pain Relief and Cold Medicines, October 2004

1298 Gershon Ben-Shakhar, Gary Bornstein, Astrid Hopfensitz and Frans van Winden, Reciprocity and Emotions: Arousal, Self-Reports, and Expectations, October 2004

1299 B. Zorina Khan and Kenneth L. Sokoloff, Institutions and Technological Innovation During Early Economic Growth: Evidence from the Great Inventors of the United States, 1790 - 1930, October 2004

1300 Piero Gottardi and Roberto Serrano, Market Power and Information Revelation in Dynamic Trading, October 2004

1301 Alan V. Deardorff, Who Makes the Rules of Globalization?, October 2004 